\title{
Cultural distance and internationalization.
}

The world's largest food and drink multinationals

\begin{abstract}
This paper analyses the expansion of the world's largest food and beverage multinational enterprises (hereafter, F\&B MNEs) over 1996-2002 using a database that provides detailed information on the location and activities of more than 8,000 affiliates. The research provides abundant empirical support to the view that $\mathrm{F} \& \mathrm{~B}$ MNEs operate on a worldwide scale and although their share of foreign to total affiliates is lower than in the average MNE they have a wide country spread. The great physical dispersion of the F\&B MNEs' assets, however, does not necessarily imply expansion to cultural distant areas. World's leaders in this industry are more likely to expand their operations to countries that display cultural characteristics similar to those of the homecountry. We observe differences concerning cultural distance among different companies. Western F\&B MNEs seem more culturally rooted than Japanese ones, probably owing to differences in the product-mix and the activities developed by the companies. A comparison of 1996, 2000 and 2002 data shows that F\&B MNEs are gradually expanding to increasingly unfamiliar environments. Complementary analysis of 3,507 M\&A operations involving the sampled MNEs between 1987 and 2003 confirms these findings.
\end{abstract}

Key words: Multinational enterprises, M\&A, affiliates, food and drink industry, cultural distance.

Subject codes: (F230, L660, M210) 


\section{Introduction}

Multinational enterprises (hereafter, MNEs) ${ }^{1}$ are often attracted by specific host-countries countries on the basis of common culture and language that could facilitate business (Goerzen and Beamish, 2003, Dunning et al., 2007). By contrast, a great cultural distance between the home-country and the host-country may contribute to hampering the internationalisation of a firm as some Firm Specific Advantages (FSAs) may display a limited scope (Collinson and Rugman, 2008). Though cultural distance has been extensively analysed in the recent economic and management literature (for a review, see Kirkman et al., 2006), it is still a topic largely overlooked in the literature, dealing more specifically with the food and beverage MNEs (hereafter, F\&B MNEs). This inquiry is, paradoxically, especially pertinent for this international industry as patterns of food consumption vary widely around the globe (Selvanathan and Selvanathan, 2006). According to anthropologists, diet and cooking are significant elements of the cultural makeup (Cavusgil et al., 2008). Some authors argue that technology based durables would be the products least connected to local cultures while food products would be the most connected (Verlegh, 2007). In summary, F\&B MNEs manufacture and sell products which are, to a large extent, culturally bound.

The primary focus of this study is to investigate whether cultural distance affects the F\&B MNEs' pattern of international expansion. After analysing internationalization patterns, over the 1996-2002 period, of the world's largest food and beverages MNEs using a database providing detailed information on the location and activities of more than $8,000 \mathrm{~F} \& \mathrm{~B}$ affiliates, we test whether companies are more likely to expand their operations to countries which display cultural characteristics similar to those of the home country (definitions below). To provide even further insights we also study the behaviour of Merger and Acquisition (M\&A) FDI, using a database 
comprising 3,507 M\&A operations undertaken by the world's largest F\&B MNEs during 1987-2003. The analysis of this form of entry is crucial since most F\&B foreign direct investment is currently coming from M\&A (not from greenfield investment)(Tozanli, 2005).

In addition to the academic interest of the question, a better understanding of the strategies of international leaders in this industry may be useful to both policy-makers and managers.

The main contribution of this paper is that it inquires for the first time whether the great physical dispersion of $\mathrm{F} \& \mathrm{~B}$ MNEs' assets implies also dispersion across different cultural areas. At first sight, these companies are highly internationalized and sell their global brands all over the world. We will argue, nevertheless, that the world's leaders in this industry are likely to primarily expand within their cultural area or to culturally close areas (definitions below).

The rest of the paper is organised as follows: Section 2 presents some key characteristics of F\&B MNEs. Section 3 sets out the theoretical background which informs our research and section 4 presents the data and methodology. Section 5 presents the descriptive statistics and the evidence concerning the internationalisation of F\&B MNEs. Section 6 displays our results on the diffusion of such companies across cultural areas while Section 7 analyses evidence concerning M\&A operations in which the sampled firms were involved in 1987-2003. Finally, section 8 concludes and implications for strategic management and public policy are discussed.

\section{Origin of capital, growth and MNEs' foreign choices}

The world's 100 largest F\&B MNEs (thereafter, the Top Group) accounted, by the mid 1990s, for around $50 \%$ of the world's patented innovations in the F\&B 
technological field (Alfranca et al., 2002) and controlled, by 2002, 27\% of the world's F\&B industry turnover (Ayadi et al., 2006).

Most of these companies are based in North America (USA and Canada) and Europe. This corroborates research based on FDI flows: although there are now many new players in the international scene, North America and the EU-15 still remain the main source and recipient areas for capital in this international industry (Fischer, 2002). The nationality-mix of the Top Group, though, is changing, with the emergence of new source countries for food and beverage Foreign Direct Investment (FDI). Increases were noticeable in the aggregated shares of affiliates pertaining, respectively, to $F \& B$ MNEs based in: i) Japan (from $17 \%$ of total in 1996 to $18 \%$ in 2000); ii) Latin America (from $9 \%$ to $11 \%$ ); and iii) other European nations (non-EU-15 countries) (from $7 \%$ to 9\%) (Tozanli, 2005).

The key argument behind this rapid internationalisation is the fact that internationalization seems to positively influence the performance of F\&B MNEs. According to an empirical study (Anastassopoulos and Rama, 2005), the F\&B MNEs which grew quicker in terms of their global sales were, in the 1990s, relatively small and capital-intensive companies which had diversified into food related technological activities and had avoided, by contrast, diversification into non-food products and retailing; in spite of their relatively small size, these dynamic companies displayed substantial country spread.

According to the International Business (IB) literature, the foreign choices of MNEs are determined, among other factors, by host-country characteristics such as political stability, reliable legal institutions, some degree of protectionism and so on (for reviews of the literature, see Caves, 1996, Flores and Aguilera, 2007). More specifically, some of the main reasons supporting an F\&B MNE's preference to invest 
in a foreign country are the existence of a large internal market, a high "per capita" gross domestic product (GDP), a large urban population, high levels of protectionism, concentrated markets, availability of cheap inputs and raw materials, and participation to trade blocks (e.g. the European Union) (Gopinath et al., 1999, Pick and Worth, 2005, Ayadi et al., 2006, Rama and Wilkinson, 2008). According to AGRODATA (see Appendix 1), the most important recipient areas and countries were, in 2000, the U.S., which accounted for $15 \%$ of the foreign affiliates owned by the Top Group, the European Union (EU-15 at the time), Australia, Brazil, China, Japan and South Africa; the rest of the world, notably most African countries, received only small shares of the total numbers of foreign $\mathrm{F} \& \mathrm{~B}$ affiliates.

Concluding, affluent countries on the one hand and very large developing countries on the other seem to especially attract F\&B MNEs. This situation is in line with the panorama of FDI in other industries. Flores and Aguilera (2007) observe, for instance, that a large population is currently becoming a major driver of US FDI, even when GDP "per capita" in the host-country is not very high. Studying F\&B MNEs, Ayadi et al (2006) observe that such companies are more attracted by developing nations with a large population and high levels of urbanisation (e.g. Brazil, Egypt, Turkey) than by more affluent developing countries which do not possess these characteristics (e.g. Kuwait).

\section{Theoretical background}

This section provides the theoretical background for the issues investigated below.

\subsection{Regional strategies}


F\&B MNEs have met constraints and challenges in Western F\&B markets, such as: a slowdown in the volume of the demand, changes in lifestyles, the emerging preferences of some consumers for fresh, organic and artisan products (Goodman, 2003, Tozanli, 2005), the entry of large tobacco and pharmaceutical firms in F\&B markets (Wilkinson, 2002) and finally, fierce competition from retailers' cheap own brands.

The response of F\&B MNEs to the above mentioned changes has been to spread to a large number of foreign markets (Anastassopoulos and Rama, 2005). However, those companies are not necessarily active in every region of the world (e.g. Africa). Most F\&B MNEs follow regional (rather than global) strategies (Filippaios and Rama, $2008)^{2}$. They tend to expand to nations located in their own region or display a biregional location strategy (e.g. EU and North America), a strategy consistent with the finding that most MNEs tend to deploy regional rather than global strategies (Rugman and Verbeke, 2004, Rugman and Girod, 2003, van Tulder et al., 2001). Other authors propose the term of semi-globalization, i.e. "situations in which neither the barriers not the links among markets in different countries can be neglected" (Ghemawat, 2003 , p. 139). In this paper, we attempt to take into account cultural linkages between nations, i.e. between the home country and the host-country of the F\&B MNE, in order to better understand F\&B MNEs' international expansion.

\subsection{Foreign direct investment and cultural distance}

A firm may face higher risks and costs when expanding beyond its home-region due to cultural distance (Osegowitsch and Sammartino, 2008). Critics of Rugman and Verbeke's (2004) regionalisation theory have suggested the need to investigate also the expansion of MNEs into different cultural areas (Dunning et al., 2007), since culturally 
similar countries may exist beyond the home-region (Osegowitsch and Sammartino, 2008).

The idea that MNEs are attracted by countries which speak the same language or have a similar culture is not new in the literature (Caves, 1996, Flores and Aguilera, 2007). The Uppsala School of Thought proposes, moreover, that companies seem to follow a sequence from their home-base to countries with greater "psychic distance" (Johansson and Vahlne 1977; Shenkar 2001). According to this theory, the sequence of penetration into different markets proceeds according to cultural similarity with the home-country of the MNE. Some examples of "psychic distance" between the homecountry and the host-country provided by this literature are differences with regard to language, education and business practices. According to theories of international production, the more dissimilar the home and the host-country are in terms of tastes, values, ethics, etc., the more difficult will be for the MNE to operate and respond to local demand (Goerzen and Beamish, 2003). Most empirical studies in the IB literature find that cultural distance increases the difficulties an MNE faces overseas (Johnson et al., 2006). An econometric study finds that large US MNEs companies, consequently, may prefer not to invest when institutional/cultural distance with the host-country is very large (Flores and Aguilera, 2007).

It is therefore evident that cultural distance seems a particularly important issue for F\&B MNEs. Beliefs and values (e.g. levels of altruism, trust and health concerns) may influence attitudes towards animal welfare, sustainable agriculture, the environment, fair trade, food safety, the implementation of biotechnology, etc. Beliefs and values may also affect eating and drinking habits. Due to cultural differences, similar lifestyles and levels of income in different countries could still lead to very different food-consumption patterns (Fischer, 2002, Traill, 1997). This situation is 
apparent, for instance, within the EU (Selvanathan and Selvanathan, 2006, Gracias.A. and Albisu, 2001). Olive oil is now available in Northern Europe at similar prices than in Mediterranean producing countries but consumption has increased little, owing to different consumers' preferences (Gracias.A. and Albisu, 2001). Different nations, moreover, may value different attributes (e.g. healthiness) of the same product. Within the EU, for instance, there are significant country differences regarding motives that drive consumption of products such as yoghourt, vegetable oil and beef (Valli et al., 1999). While previous research assumed that China would follow Western food consumption patterns as income rises, a study found that Chinese consumers are rather following similar patterns with consumers in culturally close countries, such as South Korea (Shono et al., 2000). It is thus evident that although price and income certainly play an important role with regard to eating and drinking habits, such habits are also influenced by culture.

The characteristics of food consumption may, therefore, affect F\&B MNEs' expansion patterns. Unlikely electronics good manufacturers, most food and drink processors may be unable to sell the same product in all five continents. Selling products in all different countries may require a special organisational effort on the part of the F\&B firm, as shown by case studies on Unilever, a British-Dutch company, and Procter \& Gamble, a US company ${ }^{3}$ (Rugman, 2001). Foreign food companies may need, for instance, to spend additional resources in advertisement and marketing to induce local consumers to adopt new eating habits, as shown by the examples of Kellogg, a US firm, and Unilever in Asian countries that do not eat bread (and, hence, margarine) or breakfast cereals (Cuervo-Cazurra et al., 2007, Jones, 2005). The successful international penetration of some food products (e.g. instant coffee) and brand names (e.g. Coca-Cola) has often been achieved thanks to the firm's involvement 
in intensive marketing campaigns, cooperation in the building of supermarkets or convenience stores, modifications of flavours and packaging, usage of new raw materials, etc. (Earle et al., 2001).

Such difficulties, as the ones mentioned above, seem to affect the companies' patterns of expansion. Within Europe, more than half the affiliates' sales of US F\&B MNEs take place in the UK, and to a lesser extent in Germany and the Netherlands, i.e. in countries culturally close to the US (Pick and Worth, 2005). Ning and Reed (1995), who investigated location determinants of US FDI in food and related products from 1983 to 1989 , found that the US firms tended to invest in either English speaking or European countries because these countries have similar cultural links. Conversely, in 1999, US F\&B MNEs generated in the UK the highest foreign affiliate sales out of all European countries, which could reflect the effects of the country's cultural similarity with the US (Pick and Worth, 2005). In our view, these studies need to be supplemented by an analysis of F\&B MNEs based in other nations and affiliates located in a variety of host-countries. As stated, a specific analysis of M\&A FDI in this industry is also needed. These are key contributions of this paper.

Based on the above discussion we can formulate the following hypothesis:

H1: F\&B MNEs are likely to primarily expand within their cultural area or to culturally close areas.

The cultural areas studied in this paper are defined below.

\subsection{The importance of home-regions}

A review of the literature reveals the need to consider the home-country of companies as an important variable for studying their expansion patterns. According to both the IB literature and the economic geography literature, MNEs based in different 
countries display different spatial strategies (O' hUallacháin and Reid, 1992, Friedman et al., 1992, Dunning, 1993). After reviewing the literature on the location of MNEs, Blackbourne (1982) notes that such firms "retain national identities and attitudes that influence their locational behaviour". F\&B MNEs are no exception to this respect since groups of firms based in different home-regions (e.g. the EU) display different geographic strategies (Anastassopoulos and Rama, 2005, Tozanli, 2005). Previous studies, however, do not investigate whether $\mathrm{F} \& \mathrm{~B}$ companies pertaining to different home-countries (or home-regions) display different patterns of expansion across cultural areas. For instance, are Japanese firms more prone than other F\&B MNEs to expand to the most unfamiliar areas?

Hence, we test the following hypothesis:

H2: $F \& B$ MNEs based in different home-regions display different patterns of expansion across cultural areas.

\subsection{The evolution of companies}

While some studies, published in the 1990s, propose that the firms' exposure to different cultural environments may reduce, in the medium to long run, the negative impact of cultural distance (Dunning, 1998, Casson, 1994), recent research suggests that the influence of the institutional/cultural variable on firms' international expansion could be constant (Flores and Aguilera, 2007). The Uppsala School of Thought supports, as previously stated, that companies seem to follow an investment sequence from their home-base to countries with greater "psychic distance" (Johansson and Vahlne 1977; Shenkar 2001). This thesis would imply a gradual approach regarding foreign expansion. Here, we test the following hypothesis: 
H3: F\&B MNEs are likely to show a gradual investment approach to culturally distant markets.

Finally, while corporate cultural distances are an important aspect of internationalisation, we do not attempt to analyse this topic here. The IB literature considers, however, that corporate culture reflects in part national culture (Chakrabarti et al., 2009).

\section{Data and methodology}

Data indicating MNEs' sales volume by foreign country and line of business are scarce and only available, if at all, for limited numbers of companies, activities and host-countries (Ietto-Gillies, 2002a). For these reasons our analysis is based, rather than on companies' sales or assets, on the numbers of their respective affiliates. This measure is one of the proxies proposed by the OECD (2004) to construct globalisation indicators related to MNEs. This method is also used in other empirical studies dealing with the internationalization of food and beverage companies (Rugman, 2008, Filippaios and Rama, 2008).

The sample of our research is the Top Group. The Top Group does not include exactly the same companies in 1996, 2000 and 2002 because, during this period, some firms dropped out and "new" firms entered. The last complete data at affiliate level (see below) are available for 2002 .

The list of firms analyzed was derived from the global AGRODATA database (Institut Mediterraneen de Montpellier, 1990; Padilla, Laval, Allaya \& Allaya, 1983; Rastoin et al., 1998), a database produced by the Institut Agronomique Méditerranéen de Montpellier, France (I.A.M.M) (Appendix 1). This database contains the most comprehensive information available on activities and location of the affiliates of the 
world's largest F\&B MNEs, though it has been little exploited in studies published in English. F\&B MNEs included in the database should have at least one foodprocessing plant outside the home-country and agro-food sales amounting to a minimum of US\$ 1 bn. per year (Rastoin et al., 1998). The database includes world renowned firms from a wide variety of countries, including: Anheuser Busch, Archer Daniels, Coca-Cola Company, Danone, General Mills, Heinz, Mars, Nestle, PepsiCo, Procter \& Gamble, Phillip Morris, Sara Lee and Unilever.

For each of the three years (1996, 2000 and 2002) we examined the world's 100 largest food and beverage enterprises (in terms of sales), 67 of which appeared in all three years. In total this created 300 usable observations pertaining to 135 firms (incomplete observations were excluded). The enterprises in the sample originate in different home countries and hold over 8,000 affiliates ${ }^{4}$ worldwide employing over 3 million workers. The information on these affiliates provides us with the industrial and geographical distribution of operations of mother firms.

The database includes information on: name of the affiliate; name of the parent; home-country of the company; and host-country, and main sub sector of activity (e.g. retailing) of the affiliate. AGRODATA classifies the affiliates by their main economic activities, according to their UN-International Standard Industrial Classification (ISIC) code. The selected firms are active in a variety of industries, such as meat processing, dairy products, canned specialties, spirits, etc.; whilst all are food or beverage processors, a number of them also engage in agribusiness and non-food products. Following a previous study (Rama, 1998), we group such economic activities into six main categories: within-core activities (WHITHINCORE), agriculture (AGRIC), retailing (RETAIL), technology (TECHN), international trade of agricultural products and foodstuffs (TRADE) and other activities (OTHER). Table 1 displays the 
description of the categories according to UN International Standard Industrial Classification codes.

The macro regions considered in this study are: Africa, Asia, the EU-15, Latin America (Mexico included), North America (US and Canada), Oceania and Rest of Europe (non EU-15 countries) ${ }^{5}$.

To measure cultural distance between the home and the host-country of the company we followed closely the analysis by Ronen and Shenkar (1985) and Triandis (1994), which cluster countries based on their relative similarities along four different dimensions, i.e. language, geography, wealth and religion ${ }^{6}$. In doing so, Ronen and Shenkar synthesise eight previous studies which classify countries according to aspects such as prevalent needs, values, work attitudes, etc. Most of these studies employed some types of multivariate procedure (e.g. factor analysis) to create country clusters; for details on characteristics of sampling see Ronen and Shenkar (1985).

These criteria are useful to measure cultural distance with regard to business practices encountered by MNEs in foreign countries; in addition, such aspects may also influence diet, cooking habits and conviviality. Among values, for instance, Ronen and Shenkar consider individualism as positively related to the value individuals give to personal time, an aspect also associated, in our view, to time assigned to meals. The latter varies widely across countries. A study found, for instance, that the French devoted $37 \%$ more time to eating activities than the British (Warde and Martens, 2000). Another study found that, in some countries, consumers prefer nibbling and show little interested in cooking (e.g. Scandinavian countries), while in others consumers prefer "solid" traditional meals (e.g. German speaking nations) (Askegaard and Madsen, 1998). These studies suggest that some cultures view meals largely as leisure time, while others may not. On the other hand, language, another dimension considered by 
Ronen and Shenkar's classification, may be useful to define different food cultures. A study including 138 food related questions and 20,000 respondents in 79 European regions detected a large degree of overlapping between food culture and language (Askegaard and Madsen, 1998). The popularity of some diets (e.g. "low-carb" diet) in some countries and not in others (see Miljkovic and Mostad, 2007) is, in part, attributable to the media; hence, the importance of common language for communication. GDP, another dimension of Ronen and Shenker's classification, is a key variable to explain both food consumption patterns and F\&B MNEs' attraction for specific host-countries (Selvanathan and Selvanathan, 2006, Ayadi et al., 2006). Another important point raised is that some religions prohibit the consumption of specific drinks and foodstuffs or request that food is prepared in specific forms. Finally, geography defines the regional dimension which affects, in turn, the availability of agricultural products and raw materials, physical distance between countries, etc.

This method enabled us to measure, at the affiliate level, the cultural distance between the home-country of the parent and the host country where each affiliate is located. Following Ronen and Shenkar (1985), we clustered the countries according to Figure 1, which encompasses nine country clusters (for composition of each cluster, see Appendix 1). Figure 1 should be interpreted as follows: Countries belonging to the Anglo cluster, for instance, take the value 1, countries belonging to the Germanic or Latin European clusters take the value 2 and so on so forth. Therefore, between the Anglo cluster, on the one hand, and the Germanic or the Latin European clusters, on the other, cultural distance is only 1 . This indicator of cultural distance takes value 0 , the minimum value, when the mother and the affiliate belong to the same country cluster. For instance, cultural distance between Cadbury Schweppes, a British drink multinational, and Cardbury Schweppes Australia Ltd, an Australian affiliate is zero; in 
spite of physical distance both the parent and the affiliate are located in countries included in the same cultural cluster, i.e. the Anglo cluster ${ }^{7}$. By the same token, the indicator takes value 0 when the parent is an Argentinean firm and the affiliate is located in Mexico; both countries belong to the Latin American cluster. The indicator takes the maximum value five, when the mother belongs to a cluster within the core circle and the affiliate in the "independent" category of countries, i.e. the countries not located in any of the other clusters.

The relationship between physical distance and cultural distance deserves special attention. As noted by Ronen and Shenkar (1985, p. 444), countries tend to group together geographically "because a culture spreads first to those areas nearest its 'birthplace'“. However, cultural proximity and geographic proximity are not necessarily associated. Australia, the United Kingdom and the United States, three countries pertaining to the Anglo cluster, are located in three different continents. In spite of substantial physical distance, countries in the Latin European cluster are culturally close (distance 1) to countries in the Latin American cluster. As noted by Ronen and Shenkar (1985), colonization and immigration explain such phenomena. Conversely, within large countries, such as the US, distances are somewhat greater than between countries.

On the other hand, the relative importance of physical and cultural distance for MNEs may be changing. Some authors suggest that the costs involved in physical distance are now decreasing while those related to cultural distance may be increasing since global players are being exposed to unfamiliar social norms and belief systems (Dunning, 2009). Dunning (Dunning, 2009) argues, moreover, that physical distance is likely to have mixed effects of inward FDI (for instance, it can encourage importsubstituting FDI), while cultural distance is always likely to deter FDI. 
Cultural distance may differ for different types of foreign affiliates (e.g. retailing affiliates and agricultural affiliates). As our next step, we analysed the average cultural distance for foreign affiliates in different lines of business or activities, and we calculated AGRICCULT, TRADECULT, OTHERCULT, RETAILCULT, TECHNCULT and WITHINCULT, a set of variables which measure average cultural distance for foreign affiliates operating in the above mentioned six activities and TCULT, a variable measuring total cultural distance for all the foreign affiliates of the company (See Table 2 for definitions of the variables).

\section{Characteristics of the sample and internationalisation patterns}

Table 3 displays some general characteristics of our sample. A preliminary reading of the descriptive statistics shows that the firms display substantial diversity regarding their size (although all of them are very large), performance and degree of product diversification (for definitions of these variables, see Table 2).

Table 3 also provides some descriptive statistics on the structure of the companies, by economic activity (see Functional Structure). For instance, AGRIC (T) indicates the share of affiliates (domestic and foreign) that specialize in agricultural activities over the total number of affiliates (domestic and foreign) in 1996, 2000 and 2002 (see definitions of variables on Table 2). The functional structure of the companies remained quite similar over the 1996-2002 period. The share of affiliates engaged in non-core activities, OTHER (T), was rather stable; moreover, the evolution of FOODSA suggests that the sampled firms increasingly tended to concentrate in their core business between 1996 and 2002. The empirical data do not support the prediction that the world's most important food companies are "increasingly inter-sectoral" (Constance and Heffernan, 1993 , p. 20). 
In Table 3, we calculate two indicators of internationalisation in F\&B MNEs (see Internationalisation Indicators). As mentioned before, Table 2 contains the variable descriptions for reference. FDIV measures the level of internationalisation of the firm, i.e. its foreign affiliates as a percentage of its total number of affiliates (domestic and foreign). This variable signals the relative weight of foreign versus domestic facilities within the multinational network and measures the geographic diversification of the company. The foreign affiliates of the F\&B MNEs, which amounted to $53 \%$ of the total number of affiliates (domestic and foreign) in 1990-1996 (Anastassopoulos and Rama, 2005), grew to $56.5 \%$ in 2002. The average level of internationalisation in manufacturing and mining MNEs, as measured by the same scope measure, was 58.4\% in 1997 (Ietto-Gillies, 2002b). FCOU measures the country spread of the $F \& B$ multinational, i.e. the number of foreign countries where the company operates; it indicates the geographic dispersion of the MNE's network. F\&B MNEs, which had operated, on average, in only 13 foreign countries in 1990-1996 (Anastassopoulos and Rama, 2005), spread to 19 foreign countries in 1996 and to 20 in 2000- 2002. To put these figures into a relevant perspective, consider that the average MNE spread to only 13.6 countries in 2000 (Ietto-Gillies, 2002b). We conclude from the analysis thus far that F\&B MNEs are highly internationalised. The issue left unanswered is whether such expansion takes place in familiar or unfamiliar environments. We turn to this question next.

\section{F\&B MNES' expansion across cultural areas}

In this section we investigate whether F\&B MNEs' substantial country spread also implies expansion to culturally distant areas. Our analysis is of an exploratory nature as we do not explicitly model firms' location decisions. 
The next set of variables in Table 3 measures, at the affiliate level, the cultural distance between the home-country and the host country (see Cultural Distance heading). Again, definitions of variables are in Table 2.

The most important conclusion of the analysis is that $\mathrm{F} \& \mathrm{~B}$ MNEs tend to primarily operate in foreign countries culturally close to their respective homecountries. When investing abroad, the average cultural distance met by an F\&B MNE is approximately 1 , with a large variation among companies (see TCULT in Table 3 ). This result supports $H 1$ (F\&B MNEs are likely to expand mainly within their cultural area or to culturally close areas).

As stated, there is a large variation of the TCULT variable among companies. Table 4 provides some examples.

We wish to focus now on exploring differences within the multinational network. We find some differences concerning the cultural distance faced by different types of affiliates (see Cultural Distance by Type of Activity in Table 3). Logically enough, F\&B MNEs seem more likely to somewhat spread their international trade facilities (see TRADECULT in Table 3) across cultural clusters, while strongly preferring cultural proximity for other activities (see WHITINCULT, OTHERCULT and, especially, TECHCULT in Table 3). The strong preference of F\&B MNEs for culturally close countries in the case of their R\&D affiliates is coherent with theories of the Economics of Technological Change which point to the importance of common language and culture in knowledge transmission (Mansfield, 1991). Following McCann and Mudambi (2004), another plausible explanation for the location of R\&D affiliates is that F\&B MNEs prefer to locate their newer, less standardized activities, i.e. their most valuable R\&D activities, in close cultural areas in order to avoid risk. Though different 
types of affiliates may face different levels of cultural distance, most of them are located in culturally close countries.

We explore now possible differences within the Top Group. AGRODATA provides information on the most important line of business for each firm, i.e. the line which accounts for most of its global sales. We use this information to split the sample into three groups of companies: Agribusiness, Beverage Companies and Food Processors. Though they also process food, Agribusiness are mainly engaged in business involving agro-food commodities (e.g. sugar) and inputs (e.g. seeds). Beverage Companies mainly produce alcoholic drinks and soft drinks. Agribusiness locate $25 \%$ of their foreign affiliates in the same cluster (distance 0 ) and $31 \%$ in clusters which display distance 1 with the home-country; Beverage companies locate $26 \%$ and 20\% respectively; and Food processors 32\% and 33\%, respectively, in 2002. Whatever the line of business, the companies are likely to locate most of their foreign affiliates in countries which display cultural characteristics quite similar to those of the home-country. These data also support $H 1$.

Moreover, F\&B MNEs based in North America, the EU-15, Rest of Europe, Latin America and Oceania had mainly expanded within their cultural area or to culturally close areas (distances 0 and 1) in 1996, 2000 and 2002 (Table 5). This result further supports $H 1$. Notable exceptions in this pattern are Japanese F\&B MNEs but we will further discuss their expansion later in the paper.

In the following paragraphs, we test $H 2$ (F\&B MNEs based in different homeregions display different patterns of expansion across cultural areas). The results of the analysis are displayed, at the affiliate level, in Table 5. Each F\&B MNE was firstly classified, following Ronen and Shenkar (1985), by the cultural cluster of its homecountry and, secondly, by home-region. For instance, F\&B MNEs based in Denmark 
(e.g. Carlsberg) were classified into the Nordic cluster and F\&B MNEs based in France (e.g. Danone) into the Latin European cluster. Both companies were, then, classified into the EU-15 home-region.

Results in Table 5 show that the null hypothesis of no association between the variables could be rejected: the home-region of a company and the cultural-based patterns of location followed by its foreign affiliates are statistically associated. Indicating that our findings are statistically robust, this result is confirmed for 1996, 2000 and 2002 (see Test of Association Chi-square statistics in Table 6). Faced with the challenge of expanding to cultural environments new to them, F\&B MNEs based in different home-regions follow different strategies.

This result implies that F\&B MNEs' patterns of expansion across cultural clusters differ among companies based in different home-regions. North American and European F\&B MNEs tended to keep most of their foreign affiliates still concentrated in countries culturally similar to their home-countries, while Japanese F\&B MNEs trailed a more dispersed strategy investing significantly in countries with either average or high cultural distance. During the period, European F\&B MNEs concentrated around $75 \%$ of their foreign affiliates in culturally close countries (distances 0 and 1) whilst North American F\&B MNEs concentrated nearly 60\% of theirs. By contrast, Japanese companies concentrated a small share of their foreign affiliates in culturally close countries, while they settled between $52 \%$ and $45 \%$ of total affiliates in cultural distant countries (distances 4 and 5) during the period.

In short, results support $H 2$ (F\&B MNEs based in different home-regions display different patterns of expansion across cultural areas).

These results require a further examination of the behaviour of Japanese F\&B MNEs. Obviously, these companies may be attracted by the affluent markets of North 
America and Western Europe in spite of cultural and geographic distance. Another possible explanation for their strategy is that they depend less than their European and North American rivals on specific local tastes. Many of the products marketed by Japanese F\&B MNEs require only little adaptation to foreign markets (e.g. inputs for the agro-food industry, Japanese specialities) (Florida and Kenney, 1994, Connor, 2006) Secondly, Japanese F\&B MNEs also produce meat, fish or sea food, which they export from their foreign affiliates back to Japan (Tozanli, 2005). . In short, the nature of their product-mix could make Japanese F\&B MNEs less rooted than Western firms in specific cultural environments.

A key research question of the current study is to investigate how the F\&B MNEs presence in different cultural clusters evolved during the period. To test $H 3$ we select a subsample of 67 continuous firms, i.e. companies which were in the Top Group in 1996, 2000 and 2002, and we perform a one-way repeated ANOVA test for the three lines of business (Agribusiness, Beverage Companies and Food Processors). In doing so, we use six new variables, CULTDISTAFF (0-5), which indicates the company average number of foreign affiliates in clusters where cultural distance between the home-country and the host-country, is respectively, $0,1,2,34$, or 5 . For a US company, for instance, CULDISTAFF (0) is the number of foreign affiliates of the MNE in the Anglo cluster; CULDISTAFF (1) accounts for its foreign affiliates in the Germanic and the Latin European clusters, and so on. Our results show that there is no statistically significant relationship between cultural distance and line of business (see Between Subjects in Tables $6 a, 6 b$ and $6 c)^{8}$. Then, we test for differences between the variables in 1996, 2000 and 2002 in order to detect possible changes in the multinational presence during the period. The results show that for the Low distance subsidiaries (0) and High distance subsidiaries (4 and 5) the distribution does not 
change over time $\left(F_{0}=2.02\right.$, Prob $F_{0}=0.14$, Adj $R^{2}=0.77 ; F_{4}=20.45$, Prob $F_{4}=0.64$, Adj $R^{2}=0.87 ; F_{5}=1.90$, Prob $F_{5}=0.15$, Adj $\left.R^{2}=0.74\right)$. As shown by Tables $6 a, 6 b$ and $6 \mathrm{c}$ ), we do see though a relationship between time and subsidiaries at the middle levels of cultural distance (1, 2 and 3) and results are statistically significant (See Year in Tables $6 a, 6 b$ and $6 c)$. As shown by these tables, results are not significantly affected when the line of business (Agribusiness, Beverages and Food) is controlled.

These results reveal an interesting pattern. During the period, the average French F\&B MNEs, for instance, would not be likely to increase its average number of foreign affiliates in the Latin European cluster (distance 0) nor in the Near Eastern (4) or Independent cluster (e.g. Russia) (5); however, the company would be likely to increase its presence in clusters of countries displaying medium cultural distance (e.g. Anglo, Latin American, Germanic). As stated, results are confirmed for each of the three types of business (Agribusiness, Beverages and Food). To summarise, $H 3$ (F\&B MNEs are likely to approach gradually to cultural distant markets) is supported. By contrast, our result do not support Flores and Aguilera's (2007) proposition about possible permanent institutional/cultural factors which may hamper the MNE international expansion, though the period studied here is admittedly short to deduce strong conclusions. In any case, our analysis suggests that the F\&B MNE approaches gradually the markets of cultural distant countries, corroborating the thesis of the Uppsala School of Thought.

\section{M\&A FDI and cultural distance}

One could argue, nevertheless, that our findings may not be applicable to Mergers and Acquisition (M\&A) FDI. This mode of entry may reduce some of the uncertainties facing a MNE in an unfamiliar market since the acquired company (or subsidiary) is likely to know local conditions and produce well adapted products. 
Consequently, MNEs may use this mode of entry to penetrate foreign countries that display characteristics different to those of the home-country. However, some empirical studies show the difficulties faced by F\&B MNEs who employed this mode of entry to penetrate certain cultural distant countries. In emerging economies, for instance, take-overs of local firms may be limited by regulatory constraints and scarcity of potential targets, since the resource endowment of local firms is often poor (Meyer and Tran, 2006). It could also be argued that local managers of the acquired company may help the MNE to expand in cultural distant markets. In practice, as shown by a study on Western F\&B MNE in Central and Eastern Europe, foreign investors may need to appoint expatriate managers because the local personnel is insufficiently skilled or unfamiliar with the MNE practices and values, and eventually with market economy (Chobanova, 2009). On the other hand, the study also suggests that F\&B MNEs may be reluctant to acquire local firms which process local specialties strongly related to the local cuisine. For instance, in the 1990s all the 138 state-founded food companies were privatized in Hungary, often with the participation of foreign investors; the exception were four plants which produced typically Hungarian foodstuffs. As shown by a study on foreign brewers in Poland, Lithuania, China and Vietnam, "customer loyalty to local tastes and brands creates barriers to entry for international brands" (Meyer and Tran, 2006), p.14) . Foreign investors actually needed to develop long time horizon strategies and envisage multiple acquisitions, given markets' regional fragmentation. The authors conclude that "brewing is a culturally embedded industry "(p. 22). To summarise, empirical studies suggest that M\&A FDI in this industry, as a tool for penetrating certain culturally distant countries, may involve more complexities than often believed.

As stated, to study specifically this form of entry is crucial, since most F\&B FDI is currently from M\&A (not from greenfield investment)(Tozanli, 2005). While data on 
the distribution of affiliates (Section 6) provide valuable information on the consolidated position of $F \& B$ MNEs over the years, data on the distribution of M\&A can help us to understand whether these companies' last investment projects tends to follow dominant cultural patterns. The specific analysis of recent investment projects is useful since the history of F\&B FDI in important host-countries and areas, such as China or Central and Eastern Europe, is quite young. Consequently, we analyse a database compiled by AGRODATA, which displays information on 3,507 M\&A involving the Top Group from January 1987 to June 2003 (see Appendix 1 for sources of information). The reason for considering this longer period is that the 1980s and early 1990s witnessed many operations concerning F\&B firms' restructuring and it was also a turbulent period in this international industry $\left(\right.$ Tozanli, 2005) ${ }^{9}$. Consideration of a longer period, therefore, is essential for capturing this relevant information. In the sample, $27 \%$ of the total number of these operations took place in the 1980 s, $57 \%$ in the 1990 s and $16 \%$ in the first years of the $21^{\text {st }}$ century. M\&A include "takeovers and related issues of corporate restructuring, corporate control and changes in the ownership structure of firms" (Copeland and Weston, 1992)p. 676). An acquisition occurs when a firm takes a controlling ownership interest in another company, a subsidiary of another company, or assets of another company such as a brand name. Consequently, an acquisition may involve the purchase of another firm's assets or stock, with the acquired company continuing to exist as a legally owned subsidiary. Here, M\&A include operations such as purchases of companies or subsidiaries, acquisitions of brand names, majority takeovers $(\geq 50 \%$ of capital of the target firm), minority takeovers $(<50 \%)$ and joint-ventures (JV).

The M\&A database include the following data: date of the transaction, name and home-country of the purchaser, name and home -country of the seller, and name 
and location of the targeted company (or subsidiary). The home-country of the seller and the target nation, i.e. the location of the acquired company (or subsidiary), may differ. For instance, a German MNE may acquire a Latin American affiliate owned by a US MNE in order to penetrate into the Latin American market. In this case, we focus on the cultural distance between Germany (Germanic cluster) and the Latin American cluster (not the Anglo cluster of the seller); cultural distance is, therefore, 3. Each purchaser is classified according to the cultural cluster of its home-country (in this case, the Germanic cluster) and to macro region (EU). Secondly, each operation is classified by target nation and its cultural cluster. In this example, the operation is classified into the Latin American cluster because it targets an affiliate located in Latin America. JV (17\% of the total number of operations) create a special methodological problem since they do not involve a purchaser and a seller but two investors. As we are interested in the behaviour of the Top Group, we consider that relevant partners for analysis are companies included in our sample (not domestic partners or smaller multinational partners that are not in the Top Group). When we analyse a JV located in India between Unilever and a small Spanish MNE, Chupa-Chups, for instance, we select for analysis Unilever, which is included in our sample, not the Spanish partner (which is not). In the few cases of JVs (only 41) between two sampled companies, we selected the major shareholder for analysis. Finally, we calculate the cultural distance between the homecountry of the purchaser (or the relevant partner in a JV) and the target nation.

Table 7 displays the distribution of the 3,507 M\&A operations by home-region of the purchaser (or relevant partner in a JV); and cultural distance between the purchaser's home-country and the target nation. As stated, the target nation and the seller's home-country may differ. The M\&A data confirm our previous findings based on the distribution of affiliates (Section 6). In the three periods (1980s, 1990s and 
2000s) the sampled companies principally targeted markets in close cultural clusters (distances 0 and 1). In other words, the empirical evidence on M\&A strongly supports H1 (F\&B MNEs are likely to primarily expand within their cultural area or to culturally close areas). This data suggests that F\&B MNEs may have used M\&A, in 1987-2003, to consolidate their positions in their own cultural cluster rather than to penetrate into culturally distant countries. As will be seen below, Japanese F\&B MNEs were notable exceptions to this pattern in the 1980s and 1990s but not in the 2000 .

We turn now to differences FDI between firms based in different home-regions. As shown by Table 7, Western F\&B MNEs display similar pattern s for their crossborder M\&As as their respective operations clearly target nations in close cultural clusters (distances 0 and 1). These aggregated clusters account for 96\%-82\%, 88\%-77\% and $87 \%-80 \%$ of the total numbers of transactions involving, respectively, EU, North American and other European (non EU) F\&B MNEs during the analysed period. In the 1980s and 1990s, Japanese F\&B MNEs were, as stated, the exception which confirms the rule since most of their transactions targeted nations pertaining to highly distant cultural clusters. Unlikely Western F\&B MNEs, therefore, Japanese F\&B MNEs may have used M\&A to penetrate cultural distant countries during that period. However, the situation changed in the 2000s. By the beginning of this century, Japanese F\&B MNEs tended to undertake most of their M\&A foreign operations within their cultural cluster (distance 0), though the share of the most distant cluster (distance 5) remained substantial. This result is in line with the recent shift of agro-food Japanese FDI observed by other studies. According to Tozanli (Tozanli, 2005) p. 19, Japanese F\&B MNEs displayed, between 1988 and 1999-2000, "an evolutionary path counter to the general trend" since these companies atypically increased their home-region business activities and their country-based subsidiaries. Our results are also confirmed by 
statistical sources showing the increasing share of Asia in Japanese outward FDI in food, and in farming and forestry (from $32 \%$ to $49 \%$ of total and from $14 \%$ to $42 \%$, respectively) between $1989-1994$ and $2000-2004^{10}$. These data probably reflect the increasing importance of China for Japanese agro-food firms in the last period (AgustinJean, 2006). The empirical evidence on this specific mode of entry corroborates, therefore, $H 2$ (F\&B MNEs based in different home-regions display different patterns of expansion across cultural areas).

To summarise, results based on M\&A data confirm that F\&B MNEs tend to primarily operate in foreign countries culturally close to their respective homecountries.

\section{Conclusions}

Based on two databases, one comprising information on the geographic distribution of more than 8,000 affiliates and the other on 3,507 cross-border M\&As, we have attempted to understand the expansion of the world's largest F\&B MNEs across cultural areas. The research provides abundant empirical support to the view that F\&B MNEs operate on a worldwide scale; their share of foreign to total affiliates is lower than in the average MNE but they have a wider spread to a larger number of countries.

Our research, however, shows that such wide geographic expansion is not indiscriminate but tends to follow dominant cultural patterns. Our findings reveal that the great physical dispersion of the F\&B MNEs' assets does not necessarily imply cultural dispersion. Though companies expand to a great number of countries, their activities rarely crosses over very different cultural boundaries. This finding is in line with Gowtzen and Beamish's (2003) research, which established that MNEs of all 
sectors performed better when combining dispersed assets and relatively familiar environments.

Our results corroborate and extend the results of previous research on US F\&B MNEs (Pick and Worth, 2005, Ning and Reed, 1995) to firms based in other countries. We find, however, that firms based in different countries may display different strategies. Western F\&B MNEs seem more culturally rooted than Asian (Japanese) F\&B MNEs, probably due to differences in the product-mix and the activities developed by the companies. Our results are congruent with Rugman's (2008) thesis that companies endowed with upstream FSAs, i.e. FSAs deployed in activities non directly connected with the final costumer, as many of the Japanese companies of our sample, enjoy more discretion in terms of their expansion.

We also studied the presence of 67 continuous companies, i.e. companies which were in the Top Group in 1996, 2000 and 2002, in different types of cultural clusters. The average number of $\mathrm{F} \& \mathrm{~B}$ affiliates in either close or very distant clusters did not increase, a result confirmed for Agribusiness, Beverages Companies and Food Processors. By contrast, we found statistically significant increases in the average number of foreign affiliates in clusters of countries displaying medium cultural distance from the home-country. The results do not support Flores and Aguilera's (2007) thesis on the relative permanence of institutional/cultural factors as a limitation to companies international expansion, though the period studied here is too short to deduct strong conclusions from the results. The sampled firms show changes, but not extreme ones, in a relatively short period of time. This finding agrees with the observation that changes in eating and drinking habits are slow. Though trends towards the homogenization of food and drink consumption patterns are already noticeable, the phenomenon has mainly taken place in culturally close areas, i.e. North America and 
Western Europe (Traill, 1997, see, for instance, Connor, 1994, Gil et al., 1995, Lopes, 1999, Connor, 1997).

Some practical consequences may be derived from our results. For policymakers who attempt to attract FDI to the food and beverage industry of their respective countries, companies based in culturally close nations seem to be an interesting target. On the other hand, nations which adopt some of the institutions and practices which are part of the cultural makeup of most source countries for agro-food capital may be in better conditions to attract FDI. Secondly, our results suggest that international leaders in this industry assign a major strategic role to the markets of culturally close countries. The finding suggests that, in spite of the current emphasis on global strategies both in business schools and mainstream business literature, managers of food and drink enterprises may find it useful to target the markets of culturally close countries. This strategy may be especially applicable to F\&B firms which have i) little international experience, ii) come from new source countries for food FDI; iii) market products requiring adaptation or "new" to other cultures.

The strategy followed by the F\&B Japanese MNEs of our sample provides useful lessons for managers. Production of high tech inputs and specialty products aiming at niche markets may open the doors of culturally distant areas.

Acknowledgements: The authors wish to thank Selma Tozanli for her help with the data and Juan Fernández-Sastre for research assistance.

\section{BIBLIOGRAPHY}

AGUSTIN-JEAN, L. 2006. Les investissements directs étrangers agro-alimentaires japonais en Chine et la recomposition des territories: du global au local. Géographie, Économie, Société, 8, 125-148. 
ALFRANCA, O., RAMA, R. \& VON TUNZELMANN, N. 2002. A patent analysis of global food and beverage firms: the persistence of innovation. Agribusiness. An International Journal, 18.

ANASTASSOPOULOS, G. \& RAMA, R. 2005. The Performance of Multinational Agribusinesses: Effects of Product and Geographical Diversification. In:

RAMA, R. (ed.) Multinational agribusinesses. New York and London: Haworth Press Inc.

ASKEGAARD, S. \& MADSEN, T. K. 1998. The local and the global: exploring traits of homogeneity and heterogeneity in European food cultures. International Business Review, 7, 549-568.

AYADI, N., RASTOIN, J.-L. \& TOZANLI, S. 2006. Les Operations de Restructuration des Firmes Agroalimentaires Multinationales entre 1987 et 2003. Working Paper No 8

Montpellier (France): Unité Mixte de Recherche MOISA.

BLACKBOURN, A. 1982. The impact of multinational corporations on the spatial organisation of developed nations: A review. In: TAYLOR, M. \& THRIFT, N. (eds.) The geography of multinationals. Studies in the spatial development and economic consequences of multinational corporations. London \& Canberra: Croom Helm.

CASSON, M. 1994. Internationalisation as a learning process: A model of corporate growth and geographical diversification. Revue d'Economie Industrielle, 109134.

CAVES, R. E. 1996. Multinational enterprise and economic analysis, Cambridge University Press.

CAVUSGIL, S. T., KNIGHT, G. \& RIESENBERG, J. R. 2008. International Business. Strategy, management and the new realities, New Jersey, Pearson International Edition.

CHAKRABARTI, R., GUPTA-MUKHERJEE, S. \& JAYARAMAN, N. 2009. MarsVenus marriages: Culture and cross-border M\&A. Journal of International Business Studies, 40, 216-236.

CHOBANOVA, Y. 2009. Strategies of multinationals in Central and Eastern Europe Innovation Systems and Embeddedness, Palgrave.

COLLINSON, S. \& RUGMAN, A. M. 2008. The regional nature of Japanese multinational business. Journal of International Business Studies, 39, 215-230.

CONNOR, J. M. 1994. North America as a precursor of changes in Western European food-purchasing patterns. European Review of Agricultural Economics, 21, 1173.

CONNOR, J. M. 1997. Economic Overview and Research Issues. On the Convergence of Food Systems. Agribusiness, 13, 253-259.

CONNOR, J. M. 2006. The great global vitamins conspiracy, 1989-1999. American Antitrust Institute , Working Paper No. 06-02 , 1-193

CONSTANCE, D. E. \& HEFFERNAN, W. D. 1993. Transnational corporations and the globalization of the food system. Sociology of Agriculture and Food.

COPELAND, T. E. \& WESTON, J. F. 1992. Financial Theory and Corporate policy, Reading, Massachusetts, Addison-Wesley Publishing Company.

CUERVO-CAZURRA, A., MALONEY, M. M. \& MANRAKHAN, S. 2007. Cause of the difficulties in internationalization. Journal of International Business Studies, 38, 709-725. 
DUNNING, J. 1998. Location and the multinational enterprise: A neglected factor? Journal of International Business Studies, 29, 45-66.

DUNNING, J., FUJITA, M. \& YAKOVA, N. 2007. Some macro-data on the regionalisation/globalisation debate: a comment on the Rugman/Verbeke analysis. Journal of International Business Studies, 38, 177-199.

DUNNING, J. H. 1993. The globalisation of business, London-NY, Routledge.

DUNNING, J. H. 2009. Location and the multinational enterprise: John Dunning's thoughts on receiving the "Journal of International Business Studies" 2008 Decade Award. Journal of International Business Studies, 40, 20-34.

EARLE, M., EARLE, R. \& ANDERSON, A. 2001. Food product development, Boca Raton, Boston, New York, Washington DC, Cambridge (UK), CRC-Woodhead Publishing Limited.

FILIPPAIOS, F. \& RAMA, R. 2008. Globalisation or regionalistion? The strategies of the world's largest food and beverages MNEs. European Management Journal, 26, 59-72.

FISCHER, C. 2002. Identifying key factors affecting success in international food markets. PhD, Justus Liebig Universität.

FLORES, R. G. \& AGUILERA, R. V. 2007. Globalization and location choices: an analysis of US multinational firms in 1980 and 2000. Journal of International Business Studies, 38, 1187-1210.

FLORIDA, R. \& KENNEY, M. 1994. The Globalization of Japanese R\&D: The Economic Geography of Japanese R\&D Investment in the United States. Economic Geography, 70.

FRIEDMAN, J., GERLOWSKI, D. A. \& SILBERMAN, J. 1992. What attracts foreign multinational corporations? Evidence from branch plant location in the United States. Journal of Regional Science, 32, 403-418.

GHEMAWAT, P. 2003. Semiglobalization and international business strategy. Journal of International Business Studies, 34, 138-157.

GIL, J. M., GRACIA, A. \& PÉREZ Y PÉREZ, L. 1995. Food consumption and economic development in the European Union. European Review of Agricultural Economics, 22, 385-399.

GOERZEN, A. \& BEAMISH, P. W. 2003. Geographic scope and multinational enterprise performance. Strategic Management Journal, 24, 1289-1306.

GOODMAN, D. 2003. The quality 'turn' and alternative food practices: reflections and agenda. Journal of Rural Studies, 19, 1-7.

GOPINATH, M., PICK, D. \& VASAVADA, U. 1999. The economics of foreign direct investment and trade with an application to the U.S. food processing industry. American Journal of Agricultural Economics, 81, 442-452.

GRACIAS.A. \& ALBISU, L. M. 2001. Food consumption in the European Union: Main determinants and country differences. Agribusiness. An International Journal, 4, 469-488.

IETTO-GILLIES, G. 2002a. How internationalised are EU transnationals? The Journal of Interdisciplinary Economics, 13, 13-49.

IETTO-GILLIES, G. 2002b. Transnational Corporations. Fragmentation amidst Integration, London and N.Y., Routledge.

JOHNSON, J. P., LENARTOWICZ, T. \& APUD, S. 2006. Cross-cultural competence in international business: toward a definition and a model. Journal of International Business Studies, 37, 525-543.

JONES, G. 2005. Managing governments: Unilever in India and Turkey, 1950-1980. Faculty \& Research. 
KIRKMAN, B. L., LOWER, K. B. \& GIBSON, C. B. 2006. A quarter century of Culture's Consequences: a review of empirical research incorporating Hoftede's cultural values framework. Journal of International Business Studies, 37, 285320.

LOPES, T. D. S. 1999. The impact of multinational investment on alcohol consumption since the 1960s. Business and Economic History, 28.

MANSFIELD, E. 1991. Academic research and industrial innovation. Research Policy, 20,1-12.

MCCANN, P. \& MUDAMBI, R. 2004. The location behaviour of the multinational enterprise: some analytical issues. Growth and Change, 35, 491-524.

MEYER, K. E. \& TRAN, Y. T.-T. 2006. Market penetration and acquisition strategies in emerging economies. Long Range Planning, 39, 177-197.

MILJKOVIC, D. \& MOSTAD, D. 2007. Obesity and low-carb diets in the United States: A herd behaviour. Agribusiness. An International Journal, 23, 421-434.

NING, Y. \& REED, M. R. 1995. Locational determinants of the US Direct Foreign Investment in Food and Kindred products. Agribusiness. An International Journal, 11, 77-85.

O' HUALLACHÁIN, B. \& REID, N. 1992. Source country differences in the spacial distribution of foreign direct investment in the United States. Professional Geographer, 44, 272-285.

OSEGOWITSCH, T. \& SAMMARTINO, A. 2008. Reassesing (home-)regionalisation. Journal of International Business Studies, 39, 184-196.

PICK, D. \& WORTH, T. 2005. Foreign direct investment in the U.S. food and kindred products. In: RAMA, R. (ed.) Multinational Agribusinesses. N.Y.-London: Haworth Press Inc.

RAMA, R. 1998. Growth in food and drink multinationals, 1977-94: an empirical investigation. Journal of International Food \& Agribusiness Marketing, 10, 3151.

RAMA, R. \& WILKINSON, J. 2008. Foreign direct investment and agri-food valuechains in developing countries: a review of the main issues Commodity Markets Review, 2007-2008, 51-66.

RASTOIN, J. L., GHERSI, G., PÉREZ, R. \& TOZANLI, S. 1998. Structures, performances et stratégies des groupes agro-alimentaires multinationaux, Montpellier (France), AGRODATA.

RUGMAN, A. \& GIROD, S. 2003. Retail multinationals and globalization: the evidence is regional. European Management Journal, 21, 24-37.

RUGMAN, A. \& VERBEKE, A. 2004. A perspective on regional and global strategies of multinational enteprises. Journal of International Business Studies, 35, 3-18.

RUGMAN, A. M. 2001. The End of Global Strategy. European Management Journal, $19,333-343$.

RUGMAN, A. M. 2008. A regional solution to the strategy and structure of multinationals. European Management Journal, 26, 305-313.

SELVANATHAN, S. \& SELVANATHAN, E. A. 2006. Consumption patterns of food, tobacco and beverages: a cross-country analysis. Applied Economics, 38, 15671584.

SHENKAR, O. 2001. Cultural distance revisited: towards a more rigorous conceptualization and measurement of cultural differences. Journal of International Business Studies, 32, 519-535.

SHONO, C., SUZUKI, N. \& KAISER, H. M. 2000. Will China's diet follow Western diets? Agribusiness. An International Journal, 16, 271-279. 
TEECE, D. 1985. Multinational enterprise, internal governance and industrial organization. The American Economic Review, 75, 233-238.

TOZANLI, S. 2005. The rise of global enterprises in the world's food chain. In: RAMA, R. (ed.) Multinational Agribusinesses. N.Y.: Haworth Press Inc.

TRAILL, B. 1997. Globalisation in the food industries? European Review of Agricultural Economics, 24, 390-410.

TUNG, R. L. 2008. Commentary. The cross cultural research imperative: the need to balance cross-national and intra-national diversity. Journal of International Business Studies, 39, 41-46.

VALLI, C., LOADER, J. L. \& TRAILL, B. 1999. Pan-European food market segmentation: An application to the yoghurt market in the EU. In: KAYNAK, E. (ed.) Cross-national and cross-cultural issues. New York and London: International Business Press.

VAN TULDER, R., VAN DEN BERGHE, D. \& MULLER, A. 2001. The world's largest firms and internationalization, Rotterdam (The Netherlands), Rotterdam School of Management/Erasmus University.

VERLEGH, P. W. J. 2007. Home country bias in product evaluation: the complementary roles of economic and socio-psychological motives. Journal of International Business Studies, 38, 361-373.

WILKINSON, J. 2002. The final foods industry and the changing of the global agrofood system. Sociologia Ruralis, 42, 329-346. 
Table 1. Description of categories

\begin{tabular}{|l|l|}
\hline AGRIC & $\begin{array}{l}\text { Indicates involvement of the affiliate in: agriculture, horticulture, animal husbandry, } \\
\text { viticulture, pisciculture, aviculture, silviculture, fisheries and production of seeds. } \\
\text { UN-SIC Codes: } 1110,1210,1300,1301,1302\end{array}$ \\
\hline TRADE & $\begin{array}{l}\text { Indicates involvement of the affiliate in wholesale trade of agricultural products and } \\
\text { foodstuffs } \\
\text { UN-SIC Code: } 611080\end{array}$ \\
\hline OTHER & $\begin{array}{l}\text { Indicates involvement of the affiliate in non-food industries and services (excluding those } \\
\text { classified into RETAIL and TRADE) }\end{array}$ \\
\hline RETAIL & $\begin{array}{l}\text { Indicates involvement of the affiliate in: retailing, supermarkets, hypermarkets, restaurants } \\
\text { and pubs. UN-SIC Codes: 6210, 6220, 6300, 6310 }\end{array}$ \\
\hline TECHN & $\begin{array}{l}\text { Indicates involvement of the affiliate in: technological services to other companies, } \\
\text { biotechnology, veterinarian services to farms, production of microbiological products and } \\
\text { research centres with the status of independent affiliates. } \\
\text { UN-SIC Codes: } 311280,832020,832021,832030,9320,9330\end{array}$ \\
\hline WITHINCORE & \begin{tabular}{l} 
Indicates involvement of the affiliate in food and beverages manufacturing \\
\hline
\end{tabular} \\
\hline
\end{tabular}


Table 2 Variable description

\begin{tabular}{|c|c|}
\hline Variable Name & Variable Description \\
\hline $\begin{array}{l}\text { SIZE }_{i, t} \\
\text { PERF }_{i, t} \\
\text { FOODSA }_{I, t}\end{array}$ & $\begin{array}{l}\text { Number of Employees } \\
\text { Net Income / Total Sales (Return on Sales, ROS) } \\
\text { Food Sales / Total Sales }\end{array}$ \\
\hline $\begin{array}{l}\text { FDIV }_{i, t} \\
\text { FCOU }_{i, t}\end{array}$ & $\begin{array}{l}\text { Foreign Affiliates / Total Number of Affiliates } \\
\text { Number of foreign countries in which the firm is present }\end{array}$ \\
\hline $\operatorname{AGRIC}(\mathrm{T})_{\mathrm{i}, \mathrm{t}}$ & Percentage of total affiliates operating in agricultural activities/Total no. of affiliates \\
\hline TRADE $(\mathrm{T})_{\mathrm{I}, \mathrm{t}}$ & Percentage of total affiliates operating in international trade /Total no. of affiliates \\
\hline OTHER $(\mathrm{T})_{\mathrm{i}, \mathrm{t}}$ & Percentage of total affiliates operating in non-food related activities/Total no. of affiliates \\
\hline $\operatorname{RETAIL~}(\mathrm{T})_{\mathrm{i}, \mathrm{t}}$ & Percentage of total affiliates operating in retail activities/Total no. of affiliates \\
\hline $\operatorname{TECHN}(\mathrm{T})_{\mathrm{i}, \mathrm{t}}$ & Percentage of total affiliates operating in Research \& Development related activities/Total no. of affiliates \\
\hline $\operatorname{WITHINCORE}(\mathrm{T})_{\mathrm{i}, \mathrm{t}}$ & Percentage of total affiliates operating in food \& drink related activities/Total no. of affiliates \\
\hline AGRICCULT $_{\text {IIt }}$ & Average Cultural Distance for foreign affiliates in agricultural activities \\
\hline TRADECULT $_{\mathrm{I}, \mathrm{t}}$ & Average Cultural Distance for foreign affiliates in international trade \\
\hline OTHERCULT $_{\mathrm{i}, \mathrm{t}}$ & Average Cultural Distance for foreign affiliates in non-food related activities \\
\hline RETAILCULT $_{\mathrm{I}, \mathrm{t}}$ & Average Cultural Distance for foreign affiliates in retail activities \\
\hline TECHCULT $_{\mathrm{I}, \mathrm{t}}$ & Average Cultural Distance for foreign affiliates in Research \& Development related activities \\
\hline WITHINCULT $_{\mathrm{I}, \mathrm{t}}$ & Average Cultural Distance for foreign affiliates in food $\&$ drink related activities \\
\hline TCULT $_{\mathrm{i}, \mathrm{t}}$ & Average Cultural Distance for all foreign affiliates \\
\hline CULTDISTAFF(0-5) & Average number of affiliates in clusters displaying distances from 0 to 5 with the home-country \\
\hline
\end{tabular}

Note: For definition of categories, see Table 1 
Table 3. Basic Sample Statistics

\begin{tabular}{|c|c|c|c|c|c|c|c|c|c|c|c|c|c|c|c|}
\hline \multirow[b]{2}{*}{ Variable } & \multicolumn{5}{|c|}{1996} & \multicolumn{5}{|c|}{2000} & \multicolumn{5}{|c|}{2002} \\
\hline & Obs & Mean & Std. Dev. & Min & Max & Obs & Mean & Std. Dev. & Min & Max & Obs & Mean & Std. Dev. & Min & Max \\
\hline \multicolumn{16}{|c|}{ General Characteristics } \\
\hline SIZE & 86 & 37821.35 & 67641.09 & 65.00 & 486000.00 & 104 & 31878.42 & 43826.09 & 78.00 & 261000.00 & 100 & 32803.26 & 45992.14 & 69.00 & 258000.00 \\
\hline PERF & 114 & $3.95 \%$ & $4.20 \%$ & $-11.38 \%$ & $18.83 \%$ & 111 & $3.44 \%$ & $5.92 \%$ & $-19.41 \%$ & $20.14 \%$ & 105 & $4.83 \%$ & $5.23 \%$ & $-12.58 \%$ & $22.56 \%$ \\
\hline FOODSA & 99 & $89.72 \%$ & $19.80 \%$ & $11.52 \%$ & $100.02 \%$ & 105 & $87.26 \%$ & $21.55 \%$ & $11.60 \%$ & $100.00 \%$ & 100 & $93.65 \%$ & $15.54 \%$ & $9.45 \%$ & $100.00 \%$ \\
\hline \multicolumn{16}{|c|}{ Internationalisation Indicators } \\
\hline FDIV & 100 & $53.70 \%$ & $24.21 \%$ & $3.70 \%$ & $100.00 \%$ & 100 & $55.14 \%$ & $26.16 \%$ & $5.56 \%$ & $98.30 \%$ & 100 & $56.52 \%$ & $26.93 \%$ & $7.69 \%$ & $96.92 \%$ \\
\hline FCOU & 100 & 19 & 18 & 1 & 98 & 100 & 20 & 19 & 1 & 92 & 100 & 20 & 21 & 1 & 92 \\
\hline \multicolumn{16}{|c|}{ Functional Structure } \\
\hline AGRIC(T) & 100 & $3.82 \%$ & $7.66 \%$ & $0.00 \%$ & $31.82 \%$ & 100 & $4.19 \%$ & $9.66 \%$ & $0.00 \%$ & $66.67 \%$ & 100 & $3.64 \%$ & $9.30 \%$ & $0.00 \%$ & $68.42 \%$ \\
\hline TRADE (T) & 100 & $3.31 \%$ & $5.45 \%$ & $0.00 \%$ & $28.57 \%$ & 100 & $2.76 \%$ & $5.71 \%$ & $0.00 \%$ & $30.23 \%$ & 99 & $2.99 \%$ & $7.20 \%$ & $0.00 \%$ & $50.00 \%$ \\
\hline OTHER(T) & 100 & $21.82 \%$ & $19.62 \%$ & $0.00 \%$ & $84.86 \%$ & 100 & $22.71 \%$ & $20.39 \%$ & $0.00 \%$ & $87.71 \%$ & 99 & $21.65 \%$ & $17.48 \%$ & $0.00 \%$ & $83.92 \%$ \\
\hline RETAIL(T) & 100 & $10.99 \%$ & $13.86 \%$ & $0.00 \%$ & $66.67 \%$ & 100 & $8.87 \%$ & $15.55 \%$ & $0.00 \%$ & $83.33 \%$ & 100 & $9.48 \%$ & $13.54 \%$ & $0.00 \%$ & $59.09 \%$ \\
\hline TECH(T) & 100 & $1.74 \%$ & $3.86 \%$ & $0.00 \%$ & $29.17 \%$ & 100 & $1.79 \%$ & $3.98 \%$ & $0.00 \%$ & $29.17 \%$ & 99 & $1.23 \%$ & $3.71 \%$ & $0.00 \%$ & $29.17 \%$ \\
\hline WITHIN(T) & 100 & $58.32 \%$ & $21.93 \%$ & $5.36 \%$ & $98.72 \%$ & 100 & $59.69 \%$ & $25.06 \%$ & $0.00 \%$ & $100.00 \%$ & 100 & $61.28 \%$ & $22.74 \%$ & $7.90 \%$ & $100.00 \%$ \\
\hline \multicolumn{16}{|c|}{ Cultural Distance by Type of Activity } \\
\hline AGRICULT & 34 & 0.90 & 1.18 & 0.00 & 3.57 & 36 & 0.92 & 1.22 & 0.00 & 3.57 & 33 & 0.97 & 1.22 & 0.00 & 4.00 \\
\hline TRADECULT & 51 & 1.32 & 1.38 & 0.00 & 5.00 & 41 & 1.51 & 1.47 & 0.00 & 5.00 & 41 & 1.15 & 1.35 & 0.00 & 5.00 \\
\hline REATILCULT & 91 & 0.53 & 0.76 & 0.00 & 3.33 & 86 & 0.58 & 0.84 & 0.00 & 4.83 & 87 & 0.56 & 0.81 & 0.00 & 4.86 \\
\hline OTHERCULT & 79 & 0.73 & 0.86 & 0.00 & 3.23 & 68 & 0.68 & 0.84 & 0.00 & 3.41 & 75 & 0.72 & 1.05 & 0.00 & 5.00 \\
\hline TECHCULT & 41 & 0.46 & 0.93 & 0.00 & 3.80 & 42 & 0.62 & 1.14 & 0.00 & 5.00 & 29 & 0.86 & 1.49 & 0.00 & 5.00 \\
\hline WITHINCULT & 100 & 0.94 & 0.78 & 0.00 & 4.20 & 99 & 0.96 & 0.70 & 0.00 & 3.42 & 100 & 0.93 & 0.77 & 0.00 & 3.65 \\
\hline TCULT & 100 & 0.89 & 0.73 & 0.00 & 3.57 & 100 & 0.91 & 0.67 & 0.00 & 3.74 & 100 & 0.89 & 0.72 & 0.00 & 3.78 \\
\hline
\end{tabular}

Note: Observation numbers differ because some of the companies may not own specific types of affiliates (e.g. agricultural affiliates). 
Table 4. Average cultural distance faced by selected F\&B MNEs in 1996-2000-2002 ( 0 =Lowest, $5=$ Highest cultural distance)

\begin{tabular}{|c|c|c|}
\hline Name of company & Average cultural distance & Origin of capital \\
\hline \multicolumn{3}{|c|}{$>2$} \\
\hline Ajinomoto & 2.13 & Japan \\
\hline Kikkoman & 2.77 & Japan \\
\hline Maruha Corp & 2.54 & Japan \\
\hline Suntory & 2.42 & Japan \\
\hline \multicolumn{3}{|c|}{$1-2$} \\
\hline Allied Domecq plc & 1.20 & UK \\
\hline Unilever & 1.62 & UK/The Netherlands \\
\hline Pepsico & 1.17 & USA \\
\hline Q.P.Corporation & 1.32 & Japan \\
\hline \multicolumn{3}{|c|}{$0.5-1$} \\
\hline Campbell Soup & 0.72 & USA \\
\hline Campina Melkunie & 0.54 & The Netherlands \\
\hline Cargill Inc. & 0.70 & USA \\
\hline Carslberg & 0.78 & Denmark \\
\hline \multicolumn{3}{|c|}{$0.5<$} \\
\hline Archer Daniels Midland & 0.36 & USA \\
\hline Bongrain & 0.38 & France \\
\hline George Weston Lt & 0.14 & Canada \\
\hline Grupo Modelo & 0.11 & Mexico \\
\hline
\end{tabular}

Source: Authors' calculations based on AGRODATA. 
Table 5. Distribution of foreign affiliates by cultural distance of the host-country and home-region of the parent $(\%)$

\begin{tabular}{|c|c|c|c|c|c|c|c|}
\hline Row Labels & 0 & 1 & 2 & 3 & 4 & 5 & $\begin{array}{l}\text { Grand } \\
\text { Total }\end{array}$ \\
\hline Africa & $5,56 \%$ & $22,22 \%$ & $0,00 \%$ & $72,22 \%$ & $0,00 \%$ & $0,00 \%$ & $100,00 \%$ \\
\hline Asia & $2,78 \%$ & $0,00 \%$ & $36,43 \%$ & $8,35 \%$ & $13,69 \%$ & $38,75 \%$ & $100,00 \%$ \\
\hline European Union & $36,14 \%$ & $39,23 \%$ & $13,57 \%$ & $8,25 \%$ & $0,34 \%$ & $2,46 \%$ & $100,00 \%$ \\
\hline Latin America & $24,79 \%$ & $35,54 \%$ & $39,67 \%$ & $0,00 \%$ & $0,00 \%$ & $0,00 \%$ & $100,00 \%$ \\
\hline North America & $26,61 \%$ & $33,09 \%$ & $20,55 \%$ & $15,24 \%$ & $0,69 \%$ & $3,82 \%$ & $100,00 \%$ \\
\hline Oceanie & $53,17 \%$ & $7,14 \%$ & $5,56 \%$ & $33,33 \%$ & $0,00 \%$ & $0,79 \%$ & $100,00 \%$ \\
\hline Rest of Europe & $37,24 \%$ & $37,93 \%$ & $19,08 \%$ & $2,30 \%$ & $0,00 \%$ & $3,45 \%$ & $100,00 \%$ \\
\hline Grand Total & $29,50 \%$ & $32,12 \%$ & $19,31 \%$ & $11,18 \%$ & $1,64 \%$ & $6,26 \%$ & $100,00 \%$ \\
\hline & & & & & & & $X^{2}=1938.26 * * *$ \\
\hline \multicolumn{8}{|l|}{2000} \\
\hline Row Labels & 0 & 1 & 2 & 3 & 4 & 5 & Grand Total \\
\hline Africa & $5,56 \%$ & $22,22 \%$ & $0,00 \%$ & $72,22 \%$ & $0,00 \%$ & $0,00 \%$ & $100,00 \%$ \\
\hline Asia & $0,00 \%$ & $0,00 \%$ & $36,61 \%$ & $8,20 \%$ & $13,39 \%$ & $41,80 \%$ & $100,00 \%$ \\
\hline European Union & $33,52 \%$ & $41,99 \%$ & $13,78 \%$ & $6,35 \%$ & $0,64 \%$ & $3,72 \%$ & $100,00 \%$ \\
\hline Latin America & $33,58 \%$ & $30,66 \%$ & $35,04 \%$ & $0,73 \%$ & $0,00 \%$ & $0,00 \%$ & $100,00 \%$ \\
\hline North America & $32,59 \%$ & $27,95 \%$ & $19,69 \%$ & $15,06 \%$ & $0,66 \%$ & $4,05 \%$ & $100,00 \%$ \\
\hline Rest of Europe & $31,34 \%$ & $41,44 \%$ & $20,03 \%$ & $2,40 \%$ & $0,00 \%$ & $4,79 \%$ & $100,00 \%$ \\
\hline Grand Total & $30,64 \%$ & $32,55 \%$ & $19,03 \%$ & $10,08 \%$ & $1,38 \%$ & $6,32 \%$ & $100,00 \%$ \\
\hline & & & & & & & $X^{2}=1843.50 * * *$ \\
\hline \multicolumn{8}{|l|}{2002} \\
\hline Row Labels & 0 & 1 & 2 & 3 & 4 & 5 & $\begin{array}{l}\text { Grand } \\
\text { Total }\end{array}$ \\
\hline Africa & $15,63 \%$ & $12,50 \%$ & $7,81 \%$ & $57,81 \%$ & $0,00 \%$ & $6,25 \%$ & $100,00 \%$ \\
\hline Asia & $2,71 \%$ & $0,00 \%$ & $45,80 \%$ & $6,23 \%$ & $11,65 \%$ & $33,60 \%$ & $100,00 \%$ \\
\hline European Union & $34,02 \%$ & $40,19 \%$ & $13,20 \%$ & $8,18 \%$ & $0,76 \%$ & $3,65 \%$ & $100,00 \%$ \\
\hline Latin America & $9,38 \%$ & $65,63 \%$ & $18,75 \%$ & $0,00 \%$ & $0,00 \%$ & $6,25 \%$ & $100,00 \%$ \\
\hline North America & $30,24 \%$ & $26,16 \%$ & $22,15 \%$ & $16,75 \%$ & $1,03 \%$ & $3,67 \%$ & $100,00 \%$ \\
\hline Oceanie & $33,33 \%$ & $13,33 \%$ & $17,78 \%$ & $22,22 \%$ & $6,67 \%$ & $6,67 \%$ & $100,00 \%$ \\
\hline Rest of Europe & $35,01 \%$ & $37,53 \%$ & $19,68 \%$ & $2,75 \%$ & $0,00 \%$ & $5,03 \%$ & $100,00 \%$ \\
\hline Grand Total & $29,74 \%$ & $30,16 \%$ & $20,23 \%$ & $12,26 \%$ & $1,63 \%$ & $5,98 \%$ & $100,00 \%$ \\
\hline & & & & & & & $X^{2}=1496.70^{* * * *}$ \\
\hline
\end{tabular}

Source: Authors' calculations on AGRODATA information.

Note $* * * \mathrm{p}<0.01$. For statistical accuracy, the Chi-square was calculated on the numbers of affiliates, not on the percentages. 
Table 6

a. Oneway repeated ANOVA (Affiliates with Cultural Distance 1)

\begin{tabular}{|l|c|c|c|c|c|}
\hline \multicolumn{1}{|c|}{ Source } & Partial SS & df & MS & F & Prob>F \\
\hline Between Subjects & 3219.98 & 2 & 1609.99 & 0.53 & 0.59 \\
Type & 3219.98 & 2 & 1609.99 & 0.53 & 0.59 \\
Code*Type & 193306.00 & 64 & 3020.41 & & \\
\hline & & & & & \\
\hline Within Subjects & 731.53 & 2 & 365.77 & 3.88 & 0.02 \\
Year & 731.53 & 2 & 365.77 & 3.88 & 0.02 \\
Residual & 12448.47 & 132 & 94.31 & & \\
\hline Total & 209705.98 & 200 & 1048.53 & & \\
\hline \multicolumn{7}{|l}{} \\
\hline OBS & 201 & & & \\
Adj R-squared & 0.910 &
\end{tabular}

b. Oneway repeated ANOVA (Affiliates with Cultural Distance 2)

\begin{tabular}{|l|c|c|c|c|c|}
\hline \multicolumn{1}{|c|}{ Source } & Partial SS & df & MS & F & Prob>F \\
\hline Between Subjects & 210.70 & 2 & 105.35 & 0.09 & 0.91 \\
Type & 210.70 & 2 & 105.35 & 0.09 & 0.91 \\
Code*Type & 71747.66 & 64 & 1121.06 & & \\
\hline & & & & & \\
\hline Within Subjects & 638.45 & 2 & 319.22 & 2.86 & 0.06 \\
Year & 638.45 & 2 & 319.22 & 2.86 & 0.06 \\
Residual & 14755.55 & 132 & 111.78 & & \\
\hline Total & 87352.36 & 200 & 436.76 & & \\
\hline \multicolumn{7}{|l}{} \\
\hline OBS & 201 & & & \\
Adj R-squared & 0.744 &
\end{tabular}

c. Oneway repeated ANOVA (Affiliates with Cultural Distance 3)

\begin{tabular}{|l|c|c|ccc|c|}
\hline \multicolumn{1}{|c|}{ Source } & Partial SS & df & MS & F & Prob>F \\
\hline Between Subjects & 471.16 & 2 & 235.58 & 0.43 & 0.65 \\
Type & 471.16 & 2 & 235.58 & 0.43 & 0.65 \\
Code*Type & 34825.40 & 64 & 544.15 & & \\
\hline & & & & & \\
\hline Within Subjects & 396.73 & 2 & 198.36 & 5.10 & 0.01 \\
Year & 396.73 & 2 & 198.36 & 5.10 & 0.01 \\
Residual & 5136.61 & 132 & 38.91 & & \\
\hline Total & 40829.89 & 200 & 204.15 & & \\
\hline & & & & \\
\hline OBS & 201 & & & \\
Adj R-squared & 0.809 &
\end{tabular}


Table 7. Distribution of M\&A operations by home region of purchaser (1), and cultural distance between the purchaser's home-country and the target nation (\%)

( $0=$ Lowest Distance $5=$ Highest Distance)

\begin{tabular}{|c|c|c|c|c|c|c|c|}
\hline M\&A - 1980s & 0 & 1 & 2 & 3 & 4 & 5 & Grand Total \\
\hline Grand Total & $63.86 \%$ & $26.32 \%$ & $3.45 \%$ & $2.27 \%$ & $0.22 \%$ & $3.88 \%$ & $100.00 \%$ \\
\hline Of which: & & & & & & & \\
\hline Asia & $15.63 \%$ & & & & & $84.38 \%$ & $100.00 \%$ \\
\hline European Union & $64.68 \%$ & $31.62 \%$ & $1.23 \%$ & $1.64 \%$ & $0.21 \%$ & $0.62 \%$ & $100.00 \%$ \\
\hline North America & $68.55 \%$ & $19.81 \%$ & $6.92 \%$ & $3.46 \%$ & $0.31 \%$ & $0.94 \%$ & $100.00 \%$ \\
\hline Rest of Europe & $40.43 \%$ & $46.81 \%$ & $6.38 \%$ & $2.13 \%$ & & $4.26 \%$ & $100.00 \%$ \\
\hline M\&A - 1990s & 0 & 1 & 2 & 3 & 4 & 5 & Grand Total \\
\hline Grand Total & $49.57 \%$ & $31.17 \%$ & $8.65 \%$ & $4.32 \%$ & $0.25 \%$ & $6.03 \%$ & $100.00 \%$ \\
\hline Of which: & & & & & & & \\
\hline Asia & $20.34 \%$ & $1.69 \%$ & & & & $77.97 \%$ & $100.00 \%$ \\
\hline European Union & $50.98 \%$ & $33.96 \%$ & $7.57 \%$ & $3.50 \%$ & $0.33 \%$ & $3.66 \%$ & $100.00 \%$ \\
\hline North America & $50.00 \%$ & $28.62 \%$ & $11.52 \%$ & $6.13 \%$ & $0.19 \%$ & $3.53 \%$ & $100.00 \%$ \\
\hline Rest of Europe & $46.08 \%$ & $31.37 \%$ & $13.73 \%$ & $1.96 \%$ & & $6.86 \%$ & $100.00 \%$ \\
\hline$M \& A-2000 s$ & 0 & 1 & 2 & 3 & 4 & 5 & Grand Total \\
\hline Grand Total & $44.38 \%$ & $34.96 \%$ & $9.78 \%$ & $4.17 \%$ & $1.27 \%$ & $5.43 \%$ & $100.00 \%$ \\
\hline Of which: & & & & & & & \\
\hline Asia & $55.00 \%$ & & & & & $45.00 \%$ & $100.00 \%$ \\
\hline European Union & $41.40 \%$ & $41.08 \%$ & $10.19 \%$ & $3.18 \%$ & $0.96 \%$ & $3.18 \%$ & $100.00 \%$ \\
\hline North America & $56.13 \%$ & $20.65 \%$ & $12.90 \%$ & $5.81 \%$ & $2.58 \%$ & $1.94 \%$ & $100.00 \%$ \\
\hline Rest of Europe & $22.45 \%$ & $57.14 \%$ & $4.08 \%$ & $4.08 \%$ & & $12.24 \%$ & $100.00 \%$ \\
\hline
\end{tabular}

Source: Authors' calculations based on AGRODATA

Note: (1) Or relevant partner in JV. 
Appendix 1. AGRODATA

The sources for AGRODATA are, in turn, Moody's Industrial Manual, the Fortune Directory of the 500 largest US and the 500 largest non-US corporations, the "Dossier 5.000" of the largest European companies published by Le Nouvel Economiste, Dun \& Bradstreet, and the annual reports of the enterprises, among others In English, Tozanli (2005) provides tables containing some of these data. Information on the IAMM and AGRODATA (in French) is available in the following web page: http://www.iamm.fr/default.htm.

The main source of information on M\&AS are annual company financial reports. Other sources are: companies' press books, specialized newspapers such as The Financial Times, Fortune International, Agia-Alimentation, Tokyio Business Today, and international databanks such as Hoover's, Fortune Directory, Nikkei's, etc. Some of the information on M\&A used here is available in Tozanli (2005). 
Appendix 2. Classification of Countries by Cluster

\section{Anglo-Saxon}

Australia, Canada, Hawaii (USA), Ile of Man, Ireland, Netherland Antilles,

Netherlands, New Zealand, South Africa, United Kingdom, United States of America

Arabic

Algeria, Bahrain, Brunei, Egypt, Iran, Jordan, Kuwait, Lebanon, Saudi Arabia, Syria, United Arab Emirates

\section{Far East}

Bangladesh, Cambodia, China, Fiji, Guam, Hong Kong, Indonesia, Macao, Madagascar, Malawi, Malaysia, Mali, Marianas Islands, Nepal, New Caledonia, New Guinea, Papua

N. Guinea, Philippines, Seychelles, Singapore, Solomon Islands, South Korea, Sri

Lanka, Surinam, Tahiti, Taiwan, Thailand, Vietnam

Germanic

Austria, Belarus, Bosnia, Czech Republic, Croatia, Estonia, Germany, Hungary, Latvia, Lichtenstein, Lithuania, Luxembourg, Poland, Slovakia, Switzerland, Ukraine

\section{Independent}

Israel, India, Japan, Russia

\section{Latin American}

Argentina, Bolivia, Brazil, Chile, Colombia, Costa Rica, Cuba, Dominican Republic, Equator, Guatemala, Guyana, Honduras, Isles Vierges, Jamaica, Mexico, Nicaragua, Panama, Paraguay, Peru, Puerto Rico, Santa Lucia, Salvador, Trinidad \& Tobago, Uruguay, Venezuela, Bahamas, Barbados, Bermudas, Caiman Islands,

\section{Latin European}

Albania, Belgium, Bulgaria, Cyprus, France, FYROM (Former Yugoslav Republic of Macedonia), Greece, Italy, Malta, Moldova, Monaco, Portugal, Romania, Serbia, Slovenia, Spain

\section{Near East/Africa}

Angola, Armenia, Belize, Botswana, Burundi, Cameroun, Congo, Ethiopia, Gabon, Ghana, Guinea, Ivory Coast, Kazakhstan, Kenya, Lesotho, Liberia, Morocco, Maurice, Mauritania, Mozambique, Namibia, Niger, Nigeria, Uganda, Uzbekistan, Pakistan, Reunion, Rwanda, Senegal, Sierra Leone, Soudan, Swaziland, Tanzania, Chad, Tunisia, Turkey, Yemen, Zaire, Zambia, Zimbabwe

Nordic

Denmark, Finland, Greenland, Iceland, Norway, Sweden

Source: Adapted from Ronen and Shenkar (1985) 
1 "A multinational enterprise is a firm that controls and manages production establishments located in at least two countries" TEECE, D. 1985. Multinational enterprise, internal governance and industrial organization. The American Economic Review, 75, 233-238.

${ }^{2}$ In the International Management literature, globalization is defined by a substantial presence of a MNE in different regions of the world. According to Rugmann and Verbeke (2004), for instance, global MNEs are those with around $20 \%$ of their activities in three regions (e.g. Africa) but less than $50 \%$ in any region. ${ }^{3}$ These two MNEs are included in our sample.

${ }^{4}$ Affiliates are establishments where the parent holds at least $5 \%$ of the equity share capital. In our sample, the parent controls, on average, $70 \%$ or more of share capital in $90 \%$ of the affiliates.

${ }^{5}$ These categories are quite similar to those used by some sources for FDI statistics, such as UNCTAD (EU, Other Developed Europe, North America, Africa, Asia, Latin America and the Caribbean , Oceania, CIS) (UNCTAD, 2009) or the Japanese Ministry of Finance (North America, Latin America, Asia, Mid and Near East, Europe, Africa, Oceania) http://www.mof.go.jp We use the categories to classify foreign investors by regional origin. As there are no F\&B MNEs based in CIS, the Caribbean or Mid and Near East in our sample, these macro regions were not included as home-regions.

${ }^{6}$ For criticism on the cultural distance construct and its measure, see SHENKAR, O. 2001. Cultural distance revisited: towards a more rigorous conceptualization and measurement of cultural differences. Journal of International Business Studies, 32, 519-535. As noted by Tung, the assumption of cultural homogeneity within nations is fallacious TUNG, R. L. 2008. Commentary. The cross cultural research imperative: the need to balance cross-national and intra-national diversity. Journal of International Business Studies, 39, 41-46. .

${ }^{7}$ The source of this information is the AGRODATA database.

${ }^{8}$ Results for CULDISTAFF(0), CULDISTAFF(4) and CULDISTAFF(5) are available upon request.

${ }^{9}$ The Economist, (1993). A Survey of the Food Industry. The Economist, December 4

${ }^{10}$ Authors' calculations, based on data from the Japanese Ministry of Finance. http://www.mof.go.jp/english/ 